放射線撮影系の MTF の測定にエッジを用いる方法が 古くから知られているが，精度の点からこれまであまり 測定されることがなかった。 今回, edge spread function (ESP)に 2 次多項式適合の平滑化微分フィルタをコンボ リューションさせて, ESF の微分と同時に平滑化を行っ た.この方法では，従来のエッジ法の欠点である，系の 雑音による精度の低下を少なくすることができる。この 方法によってX 線焦点の MTF 測定を行い, スリット法 と差のない結果を得た。エッジ法は他の方法と比較して， test object の位置合わせ不良による誤差や test object 自身による不鋭が少ない利点があるので，今後エッジ法 による測定精度をあげる検討を行いたい、。

\section{LSF のスリット撮影における光軸合わせ}

福島労災病院放射線科

○秋山 晋・小野威夫・渡辺一啓 東北大学医療技術短期大学部

片倉 剛

スリット法で MTF を求める場合, スリットーX 線管 のアライメントが特性の再現性に影慗を与える.今回， スリットを通過するX 線の強度を測定することにより， 正確に，しかも短時間で LSF を求めることができた。光 軸合わせが正確であれば，X 線強度は最大値を示す。各 週 1 回, 計 5 回スリット撮影を行い, MTF の再現性をテ ストした。結果は $2 \mathrm{lp} / \mathrm{mm}$ で MTF の差が0.03の範囲内 であり，再現性は満足できる結果であった，従来のよう に，一連のテスト撮影によるセンタリングの確認が不要 であり，また，スリット X 線強度を定量化することによ り，時間短縮と再現性を向上させることができた。 49. スクリーンフィルムシステムの MTF（第 2 報） 宇部興産中央病院 ○久米祐司 山口大学医学部附属病院放射線部 山内秀一・大塚昭義 橋田昌弘・上田克彦 宇部與産中央病院 大野忠正・水上裕子

今回得た MTF 值は，㵋定において再現性のよいもの と考える，精度についてはシカゴ大学での測定結果とよ く一致した。デンシトメータはサクラ PDM-5 を使用し， 濃度データのコンピュータへの自動入力, 計算の自動化 を実施した。そその結果，MTFの測定が，従来に比較して 高速高精度で行えるようになり，多様化しているスクリ ーン・フィルムシステムの画像評価にすばやく対応でき るようになった。
今後,スリット像撮影におけるアライメント等，精度 の検討，LSF のすそ補正方法の確立など，研究を重ねて ゆきたい。

\section{座長䇥䄪}

本セクションは，MTF 測定に関する演題であり 5 題 の発表があった。

演題45は，ワイアチャートによるMTF 測定である。 発表者等は，本法によるMTF 測定は，トランケーショ ンエラーの補正の必要がないという発表を行った。これ に対して，小寺 (后大医)，稲津（宮大放）等加ら，本法 では，フィルム系を用いておうり，トランケーションエラ 一は除去できないとコメントがあった，発表の中で，本 法とスリット法による測定值の比較も報告されたが，こ れらの比較を試みるより，本法によるMTF 測定が，理 論的に正確に測定できるかどうか，十分に検討するのが， まず最初の仕事だと思われた。

演題46はセグメント法によるMTF 測定の検討である。 発表者等は，手製のセグメントを用いて，2 種類の増感 紙一フィルム系の測定を行い，その結果について報告し た．セグメント法は粒状性の影響が大きく，アベレージ ングの必要性があることを強調した。発表の中で，本法 は, 特性曲線の直線部を利用できるので, 強度変換が不 要であると報告されたが，果たしてそうであろうか？

演題47は, edge spread functionによる画像解析と題 して，X線焦点分布をエッジ像から求め，これの微分に よる LSF から MTF を求めるというものであった。この とき, ESF から LSF を求める際, 従来の方法では, 誤差 が大きくなるので，これを少なくする検討を行っている。

会場から，増感紙一フィルム系のようにすその広がっ た LSFに対してエッジ法の適用が可能であるかという 質問があった。

演題48は，LSF のスリット撮影における光軸合わせ， というタイトルである，この報告の目的は, 正確な LSF 像を求めるために，スリットを通過するX 線強度を測定 する装置を考案し，この装置を用いて測定したMTFの 再現性を検討している. 結果として，この方法を用いる ことにより，短時間でしかも，再現性の高いMTFを测 定することができたと報告した。

演題49は，スクリーン・フィルムシステムの MTF(第 2 報) である，著者等は，数年前から，堌感紙一フィル ム系のMTF 測定システムにとり組んでおり，鋠度計の 改良，測定システムの改良等を手がけている.LSFのす その補正法など，まだいくつかの改良の余地が残されて いるが、今後模討されることを希望する。 